\title{
Pre-Commercial Procurement as a Key Development Source of It Services in the Public Sector - The Case of Slovenia
}

\author{
Marjeta HORJAK, Andrej KOVAČIČ
}

\begin{abstract}
The level of understanding and experience with implementing pre-commercial procurement (PCP) varies among European Union (EU) countries. Although PCP contributes to effective R\&D and innovative services, Slovenia is still unable to finish innovative projects successfully with the existing commercial procurement model. This article emphasizes the need to supplement the current Slovenian public procurement model for developing innovative services with particular reference to the European guidelines. Applying the case study approach to a Slovenian public organization, the article presents the contribution of using the PCP model in an R\&D-oriented information service. Such an approach could also be very useful outside the public sector, for all organizations wishing to manage risk and ensure their innovation is realized at the lowest cost. As a result, this article identifies and presents the experiences and best practices of successful innovative projects based on the PCP model that improve cooperation between the public organization and the service provider. These findings contribute to scientific literature and act as a guide for Slovenian regulators.
\end{abstract}

Keywords: development IT service; pre-commercial procurement (PCP); public procurement process; public sector

\section{INTRODUCTION}

Existing models and procurement systems concerning information technology (IT) in the Slovenian public sector result from methodologically and substantively poor understanding and approaches to providing IT solutions and services. The question is thus whether our projects are truly unable to be efficient - at the agreed time, at a reasonable cost and with satisfactory pre-planned contents, and we are unable to ensure the quality of large IT projects such as the Slovenian Tax Administration's information system, the e-Health project of the Slovenian Ministry of Health... which in line with the e-Health audit report of the Court of Audit of Slovenia is an example of such a badly planned and wrongly executed project. Some findings [1]:

- The project does not stem from a clear definition of strategic policies and objectives of the contracting authority (the Ministry and all stakeholders).

- inadequate coordination of the project stakeholders, the passive role of management and informatics, inadequate consideration of the role of the existing IS

- following from its position of power (coming from legislation), the Client (Ministry) together with stakeholders is not ready (able?) to define and harmonize common and individual business needs and IT requirements, and standards (data, business rules and business processes). Those requirements and standards are thus determined separately by individual suppliers, leading to content- and technologyincompatible solutions!

- The absence of strategic and process-level planning at the operational level should be replaced by "backboning", namely by gluing and technologically integrating heterogeneous software solutions from different suppliers (different technological levels and origins).

- $\quad$ The Client insists on a steady "product", a model of public procurement in which established suppliers with partial solutions rotate. The risks of project success, service quality, and financing are clearly on the customer's side. Changes to the public procurement system and the transition to a "service" model are required.
IT solutions/services providing projects are essentially innovative, mostly research, but always developmentoriented technological projects. For such public sector projects, the following definition of procurement method may be given: technology procurement is appropriate when the public sector institution orders a product or system that currently does not exist, but could be developed through the $R \& D$ process or via innovation within an acceptable time to the subscriber (customer) [2]; and must comply with, and even exceed, the client's needs. It covers the development phase and/or commercialization phase of a new product (software solution or service).

Such a form of procurement, which by definition corresponds to the IT field, requires the prior collusion or coordination of the content of the order of potential suppliers of software solutions and/or services before the contract is established. Especially when it comes to software, usually due to the poor and non-uniform definition of information needs, the existing so-called product model of software solutions provision is inappropriate. This reflects the fact that in the public administration, despite the legal formalization, business processes are not transparent and optimized so users and performers regard them as a partial rather than as a comprehensive business process; there is no progress on the definitions (harmonization) of processes, business rules, or data.

Our paper is not concerned with addressing all information products and service procurement models. We will warn about legal issues and weaknesses of the current public procurement system. The paper highlights the suitability of the Software-as-a-Service (SaaS) model and the need to use the public procurement system that is appropriate for the procurement of innovative products and services: pre-commercial procurement (PCP). In this light, it also presents experiences in the case of a project implementation service model in providing information services in a Slovenian public administration organization. 


\section{SOFTWARE-AS-A-SERVICE MODEL}

Software-as-a-Service (SaaS) is a software licensing and delivery model often referred to as software-ondemand and utilizing it is akin to renting software rather than buying it. This model is suitable for organizations with very specific software needs. It means that very complex and expensive software is needed in product development phases [39]. The provision of the software's functionality as a service is effectively changing the traditional relationship between providers and software users (clients). Traditional models of software solutions and service development provide for and require the subscriber to make payment "in advance" of establishing the project, namely before starting to use the services, while SaaS models transfer this risk to the software provider. However, SaaS users subscribe to the software rather than purchase it, usually on a monthly basis. Chappell (2012) emphasizes that the SaaS applications based on pay-as-you-go pricing model have less financial risk to the user subscribers as it is on premises application [37]. In practices SaaS pricing model basis of actual usage resources [39]. The SaaS model significantly reduces investment and business risks, and offsets the cash flow from the development phase to the phase of using the service. Shengli et al. (2017) found that SaaS becomes the best software licensing model due to its multitenancy [38]

In order to assess the model's effectiveness, we must first identify the objectives, scope, and level of service (SLA - Service Level Agreement) according to which it will be measured. From the service provider's perspective, the model is considered successful if it leads to the preestablished objectives being achieved, such as the efficient use of capacities, new customer acquisitions and expanding market share. The basic starting point for selecting such a model in terms of the price is that it is accepted by the service's recipient, which expects a fair price. The model's fairness and transparency leads to greater confidence before deciding on or concluding the business. A service model can only be regarded as successful, having already achieved the criterion of economic efficiency, if it allows subscribers to meet the strategic objectives and is at the same time accepted by both contractual partners.

\section{THE IMPORTANCE OF PRE-COMMERCIAL PROCUREMENT}

For the public sector, the process of publicly procuring a research and development (R\&D) innovative service is one of the most important topics. It is a concept that can, if successfully adopted, make a significant contribution to the public sector, such as by stimulating innovations and the national economy [3-8]. For a stronger world economy, reviving growth and restoring stability, innovations must be fostered [9]. Many researchers identify innovation as "cost cutting" [10] and as a major instrument for establishing public debt in a downward trend [9]. Uyarra \& Flanagan (2010) found that public procurement encompasses a significant part of overall demand for services and could be an effective driver of innovation. Edler and Georghiou (2007) determined public procurement to be a key source of public demand in sectors like health care and construction. However, where public demand is oriented to an innovative solution this has a significant influence on improving the service delivery [11, 12], such as Information Technology (IT) applications that users can access from any place and at any time [12]. Nowadays, the delivery of more efficient and higher quality public services is the European Union's priority [13]. Consequently, the higher level of innovation expenses in an IT solution influence a better performance service delivery that could be provided to the market $[10$, 9].

Since 2006, the EU has provided a new powerful and specific public procurement instrument in support of Research and Development (R\&D). Its main motive was to use public needs as a driver of innovations. Its power lies in the pre-commercial phase [14], covering R\&D activities such as solution exploration, design, and prototyping [8]. PCP allows a comparison of the advantages and weaknesses of alternative solutions, prototyping and testing in a step-by-step process in order to eliminate risks for the public organization and solution provider $[15,11$, 17]. To reduce the investment risk in IT solutions, it is important to use R\&D and to innovate [11]. Rolfstam (2012) sees PCP as an exception in the European procurement directives which allows direct R\&D. Sandell et al. (2016) found that this instrument is not harnessed enough to promote innovative IT solutions, even though many EU policy statements and researchers have highlighted its importance for use in the early stage of development and for achieving greater efficiency when spending public money [5]. Therefore, the needs for efficiency, productivity and quality underpin [13] the intensity of the demand for innovations. Moreover, this represents an opportunity to develop innovative solutions in public services such as health or the telecommunications sector [8]. However, the adoption of PCP reduces the R\&D implementation cost of IT solutions by $20 \%$ compared with using a commercial procurement instrument [19]. Nevertheless, PCP contributes to public procurement regulation, standardization, awareness-raising about innovations, and the sharing of experience in the global public sector.

Although PCP is excluded from EU procurement regulations, Directive 2014/24/EU (L94/65) and EU guideline COM 2007 are two important documents, in particular, for how to use the EU public procurement rules to promote R\&D and innovations [20]. The main aim of the European legal framework is to promote $R \& D$ innovations as the biggest driver of future growth in Europe by 2020 [8]. Apostol (2014) found that the EU is oriented to helping the public sector gain knowledge and be able to follow the R\&D of cutting-edge technologies required for public needs. Thus, PCP represents the results of a balancing act as it is established in European procurement directives. It features $R \& D$ in an early stage and so it is more innovation-focused than conventional public procurement regulations [7].

Many research studies have explored PCP's contribution to the development of new IT innovative solutions. A cross-border case study of five countries (Denmark, Finland, Netherlands, Sweden and United Kingdom) examines new technology and solutions being brought to market by use of a PCP process within a three- 
step competition phase. The result of this effective PCP approach, using early-phase testing functionalities identified by users, was innovative robotic technology for elderly care [16]. At that point where it is still possible to influence the design of an innovative solution, PCP allows the public sector's needs to be reconciled with those of the solution provider. Since PCP brings a prototype development phase, its benefit is the judge of most promising [7].

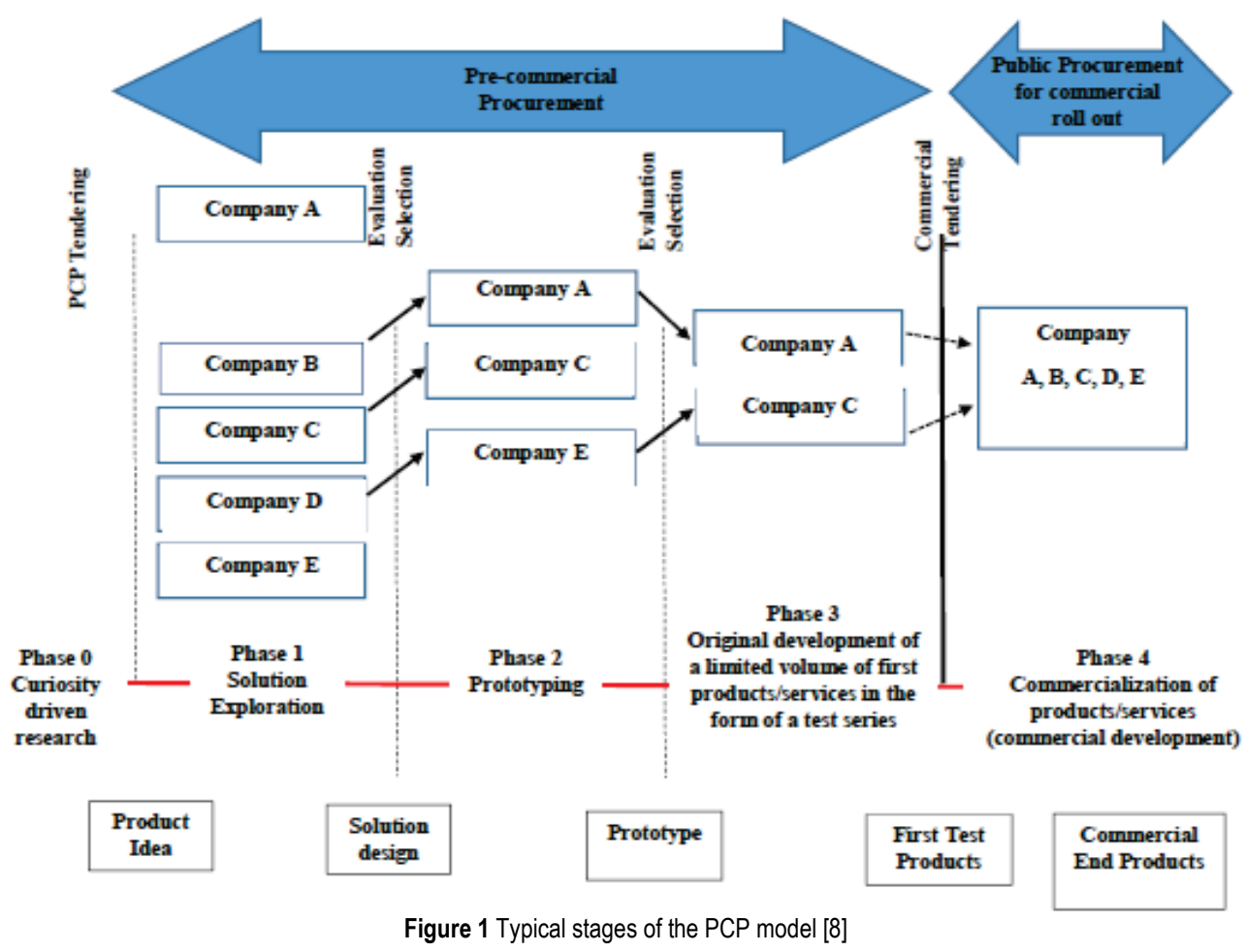

A major driver of PCP use is the desire to reduce the costs of the public sector and solution provider. PCP shares R\&D costs, meaning that each service provider and public organization absorbs its own costs of developing a solution. The solution provider enters into the development with the risk of investing in the solution if the public organization is not satisfied with the solution. Moreover, the risk for the solution provider is to cover the development costs by multiplication of sales of the solution $[8,22]$.

Following the PCP model, a public organization typically invests its own work and skills in the development solution as required defining the business and IT needs, while the solution provider invests in sources for the development solution. Such a PCP model can be applicable in organizations with a mature organizational structure that supports partnership with a solution provider, and the sharing of costs and income earned by public service provider. Its advantage is being able to realize the innovation at a lower cost [22]. However, using the PCP model for R\&D IT solutions brings new knowledge for the public sector in the early development stage, which is important for providing efficiency in processes [18].

The next R\&D-oriented case based in Italy highlights the contribution of PCP based on the design, development, and prototyping phases [13]. The results were a new technological service and a product to deliver better and more efficient public services [13].

Based on this finding, it is important to implement the European PCP instrument in the Slovenian public sector in order to stimulate interest in cooperation between the public sector and solution providers in an R\&D software solution, not only from the local region but also from global area. This approach leads to success in the optimization of public spending [23].

The clear distinction between PCP-phase R\&D and the deployment of a commercial solution encourages the public procurement sector to eliminate the technological risk of R\&D in an early stage, before making the commercial order and establishing the new innovative solution (Fig. 1).

\section{PCP IMPLEMENTATION IN THE EUROPEAN UNION}

PCP is used strategically in the United States and Asia, understanding it as a tool for encouraging R\&D innovative IT solutions. However, in the European Union it is identified a major weakness given its constant fragmentation of national public procurement policy objectives and practices, and its low orientation in R\&D and innovations in EU members [24].

The results of European Commission research (2010) provide an overview of the implementation status of PCP in the European Union (Tab. 1).

The level of understanding and experiences with implementing PCP varies in European Union countries. The first group of countries, including Slovenia, has already started with exploring the possibilities of PCP in projects. The second group of countries has already identified the framework which supports PCP in public procurement procedures. The next group of countries has already prepared a plan for how to start a PCP project, while the last group of countries has already increased activities to establish PCP due to their findings about the 
importance of PCP in R\&D projects. One of the countries starting with PCP, the Netherlands, highlights the key factors in successfully implementing innovations based on PCP: the solution provider should arise from the problems and not from the solutions, competition is between providers, a phased approach, which is to reduce risks. The PCP approach encourages cooperation and the testing of innovations prior to their introduction, thus increasing the public sector's interest in the innovation and opportunities for innovation providers (Deker, 2015). In practical terms, it is in fact "a multi-stage process, from exploration and feasibility to $R \& D$ up to prototyping, field tests with first batches and then, finally", commercial stage [11].

Table 1 Overview of PCP implementation [25]

\begin{tabular}{|c|c|c|c|}
\hline $\begin{array}{c}\text { Awareness } \\
\text { Raising } \\
\text { Exploring }\end{array}$ & $\begin{array}{c}\text { Working on } \\
\text { framework }\end{array}$ & $\begin{array}{c}\text { Framework } \\
\text { identified }\end{array}$ & Pilots started \\
\hline Latvia, Slovenia & Italy, Ireland & Finland & $\begin{array}{c}\text { BE } \\
\text { (Flanders) }\end{array}$ \\
\cline { 1 - 2 } $\begin{array}{c}\text { Greece, } \\
\text { Romania }\end{array}$ & $\begin{array}{c}\text { Sweden, } \\
\text { Spain }\end{array}$ & Denmark & $\begin{array}{c}\text { United } \\
\text { Kingdom }\end{array}$ \\
\cline { 1 - 2 } $\begin{array}{c}\text { Germany, } \\
\text { Cyprus }\end{array}$ & $\begin{array}{c}\text { Austria, } \\
\text { Lithuania }\end{array}$ & Hungary & Netherlands \\
\cline { 1 - 2 } $\begin{array}{c}\text { Bulgaria, } \\
\text { France, Slovakia }\end{array}$ & $\begin{array}{c}\text { Poland, } \\
\text { Norway }\end{array}$ & & \\
\cline { 1 - 1 } $\begin{array}{c}\text { Portugal, Czech } \\
\text { Republic }\end{array}$ & & & \\
\cline { 1 - 2 } $\begin{array}{c}\text { Estonia, } \\
\text { Switzerland }\end{array}$ & & & \\
\cline { 1 - 2 } $\begin{array}{c}\text { Luxemburg, } \\
\text { Malta }\end{array}$ & & & \\
\cline { 1 - 1 } & & & \\
\hline
\end{tabular}

Although Slovenia has an interest and the understanding of the professional public regarding PCP, a European Commission survey found that by 2010 pilot PCP projects had not yet started in the country [25]. Kovačič (2013) argues that in Slovenia the main reasons for the lack of success in establishing IT solutions are: contracting procedures which are perfectly suited to the existing large-sized IT companies (information cartel) and they thereby win public tenders due to their better knowledge of bureaucratic procedures, their lawyers and not due to better technology.

\section{PCP IMPLEMENTATION IN SLOVENIA}

Slovenia is on the right path to implementing the $2^{\text {nd }}$ phase of the PCP model by defining the framework which supports pre-commercial public procurement procedures. The Public Procurement Act (ZJN-3) entered into force on 1 April 2016 and defines the process of preparing a preliminary verification of the market prior to the involvement of solution providers and the subscriber (customer) [26].

The Digital Strategy 2020 promotes the principle of PCP in developing innovative solutions and transferring the results of innovative IT solutions/services to the market as soon as possible (Republika Slovenija, 2016). Further, the guidelines for public procurement of IT solutions (Ministrstvo za javno upravo, 2017) determine the implementation of a technical dialogue according to article 64 of ZJN-3 [26]. These guidelines also define the development solution based on analysis, the technical specification of the subscriber, and the publishing of the public procurement for developing IT solutions (Fig. 2).

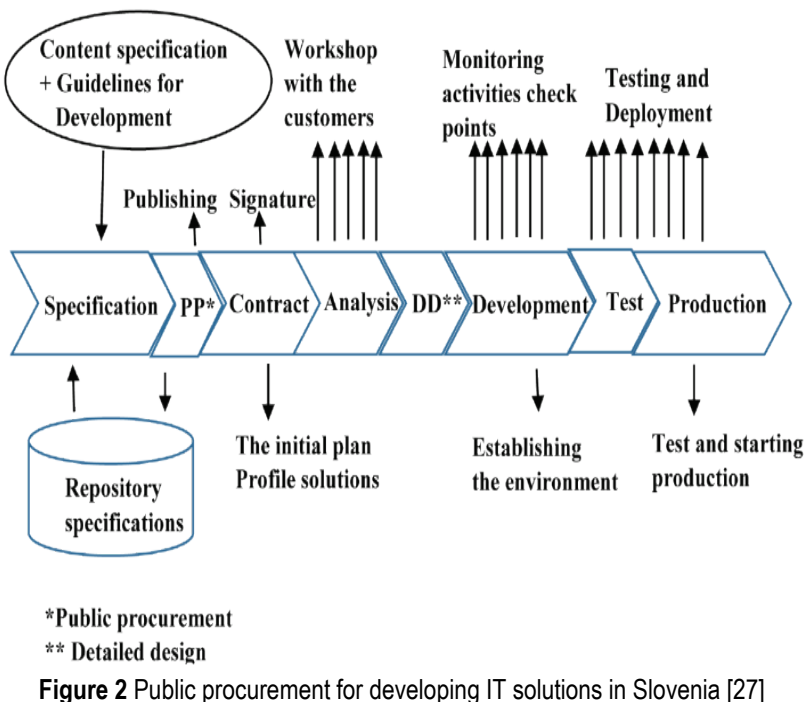

For developing a solution that has no available market yet, in Slovenia the guidelines for public procurement of IT solutions (Ministrstvo za javno upravo, 2017) under Article 43 of the ZJN-3 [26] propose a partnership for the innovation. The use of functional specifications that allow flexible innovative solutions to be proposed is the fundamental principle of public procurement [27]. Edler and Georghiou, 2007, 954) emphasize "the more innovative is innovation the more likely pre-commercial procurement can be appropriately applied", which means as a "multi-stage process, from exploration and feasibility to $R \& D$ up to prototyping, field tests with first batches and then, finally, commercialization." "Multi stage model is the predominant method for modelling the relationship between innovation and performance for any of public organization" [28].

Therefore, the current public procurement model in Slovenia for R\&D-oriented IT projects needs to be adapted in the light of EU guideline COM 2007. Further, the current public procurement model should be modified in order to meet the progress of PCP in ongoing or finished projects as is typical for most European countries (Tab. 2). Yet PCP brings the opposite to the current commercialization of public procurement $R \& D$ solutions in Slovenia. In practice, this means that in pre-commercial phase $R \& D$ (Fig. 1) it is in phases $0,1,2$, and 3 of the Slovenian public procurement model that should establish activities relating to the study of the solution (research, demonstrating and testing the prototype) and not the activities of commercial development (Fig. 2).

\section{THE EU EXPERIENCE WITH PCP IN R\&D IT SOLUTIONS}

The European Union (2015) follows the PCP concept when implementing its $R \& D$ and innovative IT projects. Zilgalvis (2015) highlights 25 IT eHealth projects that follow PCP procurement. The Relief project is oriented to IT innovative management and pain relief of chronic patients. The Dem\&Care project with IT innovation allows health parameters of persons with dementia to be 
monitored. The best practice PCP is the project case of the development application No Tremor, which is based on virtual physiological and neuromuscular models aimed at improving the quality of the analysis-based prediction of Parkinson's disease. The IT Welcome project is oriented to helping patients with chronic obstructive pulmonary disease (COPB). In its development of innovative healthcare solutions it is involving Greece, Great Britain, Ireland, Germany and the Netherlands. Further, in the case of technological development of the CARRE IT innovation, Greece, Great Britain, and Poland are included, while in the innovative application development project DO CHANGE Belgium, the Netherlands, Spain and Taiwan are included [29].

A case study of a public procurement system for Maritime in Norway identified that the innovation could be ordered in accordance with its public procurement legislation. The study findings revealed that the PCP concept provides a clear view of the results of public procurement and the selection of a suitable solution provider capable of supplying all elements of the IT innovation [7] to the public organization.

In addition, a European IT project for establishing a cloud-platform service is being conducted based on the PCP model by a consortium of solution partners from Germany, Poland, the USA, Canada, the Netherlands and the Nordic countries [30]. Countries that had PCP projects under way in 2015 are presented in Tab. 2.

Table 2 PCP projects underway in EU countries in 2015 [31]

\begin{tabular}{|c|c|c|c|}
\hline $\begin{array}{c}\text { Awareness } \\
\text { Raising } \\
\text { Exploring } \\
\text { possibilities }\end{array}$ & $\begin{array}{l}\text { Working on } \\
\text { framework }\end{array}$ & $\begin{array}{l}\text { Framework } \\
\text { and/or pilots } \\
\text { in } \\
\text { preparation }\end{array}$ & $\begin{array}{l}\text { PCP projects on- } \\
\text { going or finished }\end{array}$ \\
\hline Malta & Latvia & Lithuania & Estonia, Finland \\
\hline Bulgaria & Luxemburg & Poland & Sweden, Romania \\
\hline Cyprus & Iceland & $\begin{array}{c}\text { Czech } \\
\text { Republic }\end{array}$ & $\begin{array}{c}\text { Ireland, UK, Italy, } \\
\text { France, Austria }\end{array}$ \\
\hline Slovenia & \multicolumn{2}{|c|}{ Hungary } & Netherland, Greece \\
\hline & & & Spain, Germany \\
\hline & & & Norway, Slovakia \\
\hline & & & $\begin{array}{l}\text { Portugal, } \\
\text { Denmark }\end{array}$ \\
\hline & & & Switzerland, Belgium \\
\hline
\end{tabular}

Pomey et al. (2015, p. 38) emphasize that PCP experiences can be a source of inspiration in public organizations seeking to improve their processes and results. In "healthcare organizations wishing to change their philosophy of care and willing to benefit from their patients' experience to improve their processes and results".

Ireland is one of the European countries that has already finished PCP projects. Gormly (2014) found that PCP is used in practice by more than half of public organizations in Ireland.

\section{CASE STUDY}

\subsection{Use of PCP and SaaS in Assuring IT Services}

The aim of the project to provide information services in the public sector was the renovation and computerization of the entire procurement process in a large Slovenian public sector organization, starting with the sub-processes: (a) planning, budgeting, and monitoring the use of resources, continuing with (b) the procurement of goods and services, (c) their commitment and (automatic) liquidation of suppliers' invoices, and ending in (d) finance, accounting, monitoring and control of business transactions (Material and Cost Accounting, Accounts Payable, and General Ledger).

First, in accordance with the business strategy of the organization it was necessary to define the project's purpose and objectives and the criteria to achieve these objectives, namely, actual realization of the project. It was then necessary to define and renovate business processes of the parent organization and its 25 members, and choose an appropriate model for computerization of these processes. The service model of providing information services was selected. Since the current offer in the market of IT solutions and services did not sufficiently cover the planned information needs, it was necessary to choose an innovative methodological approach and appropriate public procurement method (PCP). The rule transformation approach to business renovation [34, 35] was used. This methodology was successfully employed in several other projects of the Institute for Business Informatics (IPI), Faculty of Economics, Ljubljana [36]. It has been shown to be suitable because it combines the benefits of the service model and the PCP method. Fig. 3 shows the progress, individual project method (PCP and outside PCP), key inputs and outputs of individual phases, their time duration and the number of providers involved in the project.

In the first step (in phase 0, outside PCP) in the project, we have to: (a) assess the appropriateness of the existing informatization and implementation of business processes, which took place in several different (non-uniform) units of the organization; (b) define a common strategy (goals and assessment criteria - KPIs) for the process renovation and unification; (c) develop a (not detailed) process model of the existing (AS-IS) and planned processes (TO-BE), with defined key data and business rules at the level of business activities. In doing so, we have also identified some new and additional business rules and procedures (Ordering and procurement, commissioning services, posting of costs to cost drivers ...). Finally, we have identified the organizational, HR, technical-technological and economic implementation bases of the procurement process' renovation and informatization.

Through the model of to-be processes, and the defined business rules and technology requirements, we have created an application (invitation, tender) with which we have entered into a contact with potential suppliers (PCP Phase 1). Two of the eight (technically skilled and technologically equivalent) agreed to present and analyze their solutions to the procurement process informatization.

We introduced both of them to the concept of a service model, which will be based on our business relationship, and they were both prepared to use its solution as a prototype. The test solution will, if satisfied, be used in the next stage of the PCP (Phase 2). Two suppliers whose prototype solution regarding the procedural and substantive terms largely covers our requirements, and which offered appropriate conditions for the provision of 
information services (SLA), were selected as a potential contractor.

In the third stage of the PCP (Phase 3), we are working together with the successful tenderers on testing and improving the selected solutions, and we are preparing real data to assess how they are processed in limited scale test cases. We are thus finding and resolving the remaining substantive issues that were also unresolved in our baseline requirements (Phase 0 ).
On the basis of the contract in Phase 4, one final provider was selected which, we believe, will as contractor and further developer of the software solution be able to provide the agreed information services (SLA) and to cover our business and IT needs the best and to the greatest extent. Because our users have been actively involved in developing and updating the selected prototype, there were no additional problems (or potential resistance) with the introduction and use of the finished product.

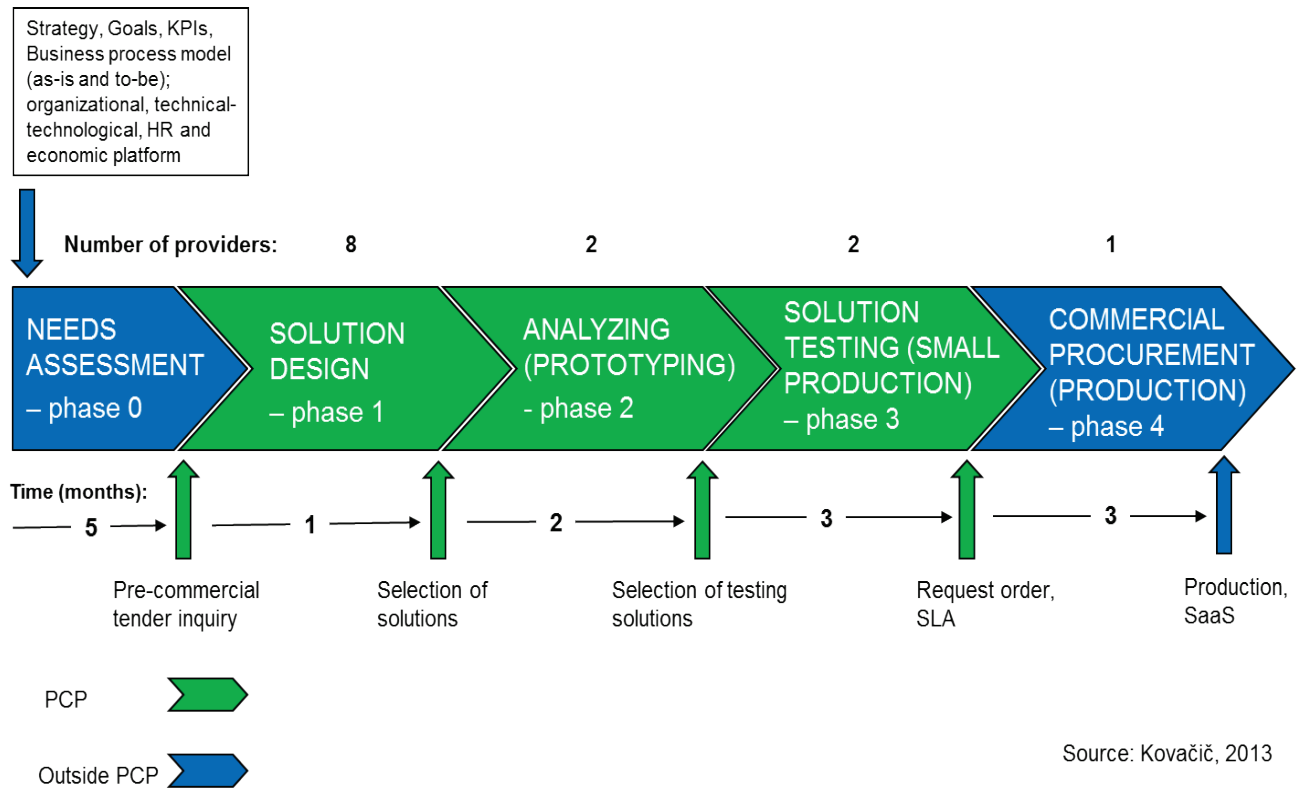

Figure 3 Procurement process renovation and informatization project

\subsection{Lessons Learnt: Why was the Chosen Service Model in Relation to PCP?}

The procedure of making a contract for the delivery of IT solutions and/or services requires organizations to apply the appropriate procurement model that meets their business objectives. Different models offer different advantages and lead to different risk levels for both the provider and the subscriber. For the subscriber, the primary risk is associated with the quality of the services, while for the service provider the financial success, longevity, and profitability of the business are important. The service model shares the risks of the contractual partners, and predefines the price and level of service provided by a supplier.

Thus, as an external service provider the client shared its own costs of providing the service, in some cases (not in our case) also the development of solutions needed for this, and the revenue generated by the new solution and/or service with third partners. The provider enters into the business with the risk of investing in the project and the possibility the client will not be satisfied with the service. Maybe the client will cover the development costs only by the multiplication of sales of the solution to new subscribers. Typically (in our case), the client invests its own work and skills necessary to define the business and IT needs, at no additional cost, the provider provides the resources required for development of the software solution, which will later provide IT services. The level of the advanced investment is subject to negotiation and the foundation for a possible split ratio from a later return on the investment. The research is limited on a single case study approach in Slovenian public organization. This limits the ability for empirical generalization. The model can be successful in cases (not in our case) where the organization has a mature organizational structure that supports the partnership and cooperation model with external service providers, and it is willing to share the realized gains with them. Also, this model (our case) has the benefit of an organization that seeks to realize its innovation at the lowest cost.

Based on the project carried out, we find that the service model of providing information services in relation to pre-commercial procurement procedures can be feasible and successful in the Slovenian public sector. Such an approach can also be very useful outside the public sector, for all organizations wishing to manage risk and to realize their innovation at the lowest cost possible.

\section{CONCLUSION}

Public service innovations have a positive impact on productivity, public service efficiency and access to public services. Therefore, the European Union's aim is to provide a public procurement model for R\&D-oriented IT solutions that promotes the benefits of the innovation and increases the quality of public services. Innovations are one of the key motives for supporting PCP and that is why the European Union is forcing use of the PCP model in EU countries. The PCP model in practice promotes innovation in a few cases in Slovenia, although the EU's experiences of IT innovation projects emphasize the importance of 
public procurement to support "the early stages of development" not only by achieving greater efficiency in the public sector through spending "but also as a vehicle for innovation and local economic development" [5].

The experiences of EU countries using PCP for information services stress its technological contribution, improvements to the operational efficiency of innovation and also the shared development and implementation risk of innovation. The stage of readiness to implement PCP varies among EU countries. In Slovenia, the main reason for the unsuccessful R\&D information service is the commercial approach taken to the public procurement process, but awareness of PCP projects is being raised and possibilities are being explored.

The case study in the Slovenian public sector shows that PCP is feasible in developing an information service and provides the basis for success in implementing information services. It is particularly important that the current procurement procedure does not lead to a high level of information projects being successfully realized. These findings represent a new scientific contribution and guidelines for Slovenian regulators.

To ensure a sustainably innovative and quality public service, we recommend use of the PCP model for the public procurement of information services in Slovenian health and education because it helps promote the development of information services.

In this article, we found that the current Slovenian public procurement model for $R \& D$ oriented to an information project should be complemented with a PCP pre-commercial phase in order to provide activities like research, demonstration, prototype, and test development. This need to supplement the procurement model is stressed in the opinion of the Računsko sodišče (the Court of Audit) in order to avoid purchasing information services and entering into a commercial contract before actually needed. The consequences of commercialization lead to unsuccessful realization of IT projects in the public sector. However, use of PCP facilitates the optimization of public spending.

\section{REFERENCES}

[1] Računsko sodišče. https://www.rs-rs.si/rsrs/rsrs.nsf/I/.../ \$file/ProjekteZdravjeRSP.pdf (15.3.2017)

[2] Edquist, C., Hommen, L., \& Tsipouri, L. (2000). Public Technology Procurement and Innovation, Kluwer Academic. Economics of Science, Technology and Innovation. https://charlesedquist.files.wordpress.com/ 2015/05/2000-ptpi.pdf (15.3.2017)

[3] European Commission. (2014). The Digital Agenda Toolbox. http://publications.jrc.ec.europa.eu/repository/ bitstream/JRC88896/ipts\%20jrc\%2088896\%20(online)\%20 final.pdf (12.01.2017)

[4] Stern, P., Hellman, J. Rijnders-Nagle, M., Terrell, M., \& Aström, T. (2011). How Public Procurement can stimulate Innovative Services. http://www.nordicinnovation.org/ Global/_Publications/Reports/2011/201102_(17.01.2017)

[5] Uyarra, E. \& Flanagan, K. (2010). Understanding the Innovation Impact of Public Procurement. European Planning Studies, 18(1), 123-143. https://doi.org/10.1080/09654310903343567

[6] Aschhoff, B. \& Sofka, W. (2009). Innovation on demandCan public procurement drive market success of innovations? Research Policy, 38(8), 1235-1247. https://doi.org/10.1016/j.respol.2009.06.011

[7] Rolfstam, M. (2012). Understanding Public Procurement of Innovation: Definitions, Innovative types and Interaction modes. Denmark, Europe: SSRN, Aalborg.

[8] Commission of the European Communities. (2007). Communication form the Commission to the European Parliament, the Council, the European Economic and Social Committee and the Committee of the regions. COM (2007) 799 final. http://eur-lex.europa.eu/LexUriServ/LexUriServ. do?uri=COM:2007:0799:FIN:EN:PDF (22.1.2017)

[9] OECD. (2012). Policies for a revitalisation of Japan. https://www.oecd.org/general/50190618.pdf (12.02.2017)

[10] Cainelli, G., Evangelista, R., \& Savona, M. (2004). The impact of innovation on economic performance in services. The Service Industry Journal, 24(1), 1-11. https://doi.org/10.1080/02642060412331301162

[11] Edler, J. \& Georghiou, L. (2007). Public procurement and innovation - Resurrecting the demand side. Research Policy, $36,949-963$ https://doi.org/10.1016/j.respol.2007.03.003

[12] Siddiquee, A. N. (2007). Public service innovations, policy transfer and governance in the Asia-Pacific region: The Malaysian experience. JOAAG, 2(1), 81-91.

[13] Clermont, F. \& Fionda, F. (2016). A Modern Approach for Procuring Research and Innovation: The Pre-Commercial Public Procurement. European Procurement \& Public Private Partnership Law Review, 11(2), 88-96.

[14] Edquist, C. \& Zabala-Iturragagoitia, J. M. (2015). Precommercial procurement: a demand or supply policy instrument in relation to innovation? $R \& D$ Management, 45(2), 147-161. https://doi.org/10.1111/radm.12057

[15] European Commission. (2016). Innovation Procurement. https://ec.europa.eu/digital-singlemarket/en/innovationprocurement (19.03.2017)

[16] Sandell, A. M., Hazell, J., \& Dakker, C. (2016). PreCommercial Procurement enabling care innovations fort the elderly. International Journal of Integrated Care, 16(6), A384, 1-8.

[17] Lember, V., Kalvet, T., \& Kattel, R. (2011). Urban Competitiveness and Public procurement for Innovation. Urban Studies, 48(7), 1373-1395. https://doi.org/10.1177/0042098010374512

[18] Lember, V., Kattel, R., \& Kalvet, T. (2014). Public Procurement and Innovation: Theory and Practice. Public Procurement, Innovation and Policy, 13-34. https://doi.org/10.1007/978-3-642-40258-6_2

[19] European Commission. (2014). The Digital Agenda Toolbox. http://publications.jrc.ec.europa.eu/repository/ bitstream/JRC88896/ipts\%20jrc\%2088896\%20(online)\%20 final.pdf (27.02.2017)

[20] Apostol, R. A. (2012). Pre-commercial procurement in support of innovation: Regulatory effectiveness? Public Procurement Law Review, 21(6), 213-225.

[21] Apostol, R. A. (2014). Pre-commercial procurement regulatory effectiveness? De graad van Doctor aan de Univeristeit Leiden. https://openaccess.leidenuniv.nl/ bitstream/handle/.../NUWD\%20Kennisportaal.url1.pdf? (27.02.2017)

[22] Kovačič, A. (2013). Projekti zagotavljanja informacijskih storitev: kako do ustreznejših modelov in sistema javnega naročanja. URL:iju2013.iju-konferenca.si/.../04.KOvačič\% 20 A. Projekti\%20zagotavljanj (12.01.2017).

[23] Tsanidis, V. (2016). Innovation Procurement. http://ec.europa.eu/information_society/newsroom/image/d ocument/2016-37/synergies_innovation_procurement updatewp2017_16968.pdf(22.01.2017)

[24] European Commission. (2006). Pre-commercial Procurement of Innovation. ftp://ftp.cordis.europa.eu/ $\mathrm{pub} /$ ist/docs/pre-commercial procurement of innovation. pdf (12.01.2017) 
[25] European Commission. (2011). Compilation of Results of the EC Survey on the status of implementation of Precommercial procurment Across Europe. http://cordis.europa.eu/fp7/ict/pcp/pcp-survey.pdf (20.02.2017)

[26] Zakon o javnih naročilih (ZJN-3). Ur. List RS, no. 91/2015).

[27] Ministrstvo za javno upravo. (2017). Smernice za javno naročanje informacijskih rešitev. https://nio.gov.si/.../ smernice+mju+za+razvoj+informacijskih+resitev-734 (20.03.2017)

[28] Hashi, I. \& Stojcic, N. (2010). The impact of innovation activity on firm performance using a multi-stage model: Evidence from the Community Innovation Survey 4. Warsaw Bishkek Kviv Tbilisi Chinau Minsk No. 410/2010. https://www.files.ethz.ch/isn/121832/410.pdf (01.02.2017)

[29] Zilgalvis, P. (2015). eHealth projects. Research and Innovation in the field of ICT for Health and Wellbeing: an overview. https://ec.europa.eu/digital-agenda/en/news/ ehealth-projects-research-and-innovation-field-ict-healthand-wellbeing-overview (03.02.2017)

[30] European Commission. (2017). HNSciCloud PreCommercial Procurement Tender Results Announcement Ceremony \& Design Phase cik off. https://ec.europa.eu/ digital-single-market/en/news/hnscicloud-pre-commercialprocurement-tender-results-announcement-ceremonydesign-phase-kick (17.02.2017)

[31] European Commission. (2015). Introduction to Innovation Procurement. http://ec.europa.eu/information_society/ newsroom/image/document/2015-50/introduction_to_ innovation_procurement_12528.pdf (28.01.2017)

[32] Pomey, P.M., Hihat, H., Khalifa, M., Lebel, P., \& Neron, A. (2015). Patient partnership in quality improvement healthcare services: Patients inputs and challenge faced. Patient Experience Journal, 2(1), 29-42.

[33] Gormly, J. (2014). What are the challenges to sustainable procurement in Commercial semi-state bodies in Ireland? Journal of Public Procurement, 14(39), 395-45.

[34] Kovačič, A. (2003). The rule transformation approach to business renovation. Business Rules Journal, 4(8), 8-20.

[35] Kovačič, A. (2004). Business renovation: business rules (still) the missing link. Business Process Management Journal, 20(2), 158-170. https://doi.org/10.1108/14637150410530235

[36] IPI (2016). http://www.ef.uni-lj.si/IPI/Publikacije (22.02.2017)

[37] Chappell, D. (2012). How SaaS Changes an ISV's Business. http://www.davidchappell.com/writing/white_papers/How_ SaaS_Changes_an_ISVs_Business--Chappell_v1.0.pdf (13.06.2017)

[38] Shengli Li, Shing, K. C., Yang, D., \& Yu-Chen, Y. (2017) A Study of Enterprise Software Licensing Models. Journal of Management Information Systems, 34(1), 177-205. https://doi.org/10.1080/07421222.2017.1297636

[39] Goncalves, V. \& Ballon, P. (2011). Adding value to the network: Mobile operators' experiments with Software-as-aService and Platform-as-a-Service models. Telematics and Informatics, 28(1), 12-21. https://doi.org/10.1016/j.tele.2010.05.005

\section{Contact information:}

Marjeta HORJAK, PhD

University of Ljubljana, Faculty of Economic,

Kardeljeva ploščad 17, 1000 Ljubljana, Slovenia

+0038631367757, marjeta.horjak@gmail.com

Andrej KOVAČlč, PhD, Full Professor

University of Ljubljana, Faculty of Economic,

Kardeljeva ploščad 17, 1000 Ljubljana, Slovenia

andrej.kovacic@ef.uni-lj.si 